\title{
Evaluating manta ray mucus as an alternative DNA source for population genetics study: underwater-sampling, dry-storage and PCR success
}

Tom Kashiwagi, Elisabeth A Maxwell, Andrea D Marshall, Ana B Christensen

Sharks and rays are increasingly being identified as high-risk species for extinction, prompting urgent assessments of their local or regional populations. Advanced genetic analyses can contribute relevant information on effective population size and connectivity among populations although acquiring sufficient regional sample sizes can be challenging. DNA is typically amplified from tissue samples which are collected by hand spears with modified biopsy punch tips. This technique is not always popular due mainly to a perception that invasive sampling might harm the rays, change their behaviour, or have a negative impact on tourism. To explore alternative methods, we evaluated the yields and PCR success of DNA template prepared from the manta ray mucus collected underwater and captured and stored on a Whatman FTATM Elute card. The pilot study demonstrated that mucus can be effectively collected underwater using toothbrush. DNA stored on cards was found to be reliable for PCR-based population genetics studies. We successfully amplified mtDNA ND5, nuclear DNA RAG1, and microsatellite loci for all samples and confirmed sequences and genotypes being those of target species. As the yields of DNA with the tested method were low, further improvements are desirable for assays that may require larger amounts of DNA, such as population genomic studies using emerging next-gen sequencing. 
1 Tom Kashiwagi ${ }^{1,2,4^{*}}$, Elisabeth Ann Maxwell ${ }^{3}$, Andrea Denise Marshall ${ }^{2}$, Ana Beardsley

2 Christensen ${ }^{3}$

$3 \quad{ }^{1}$ Molecular Fisheries Laboratory, University of Queensland, St. Lucia, QLD 4072, Australia

$4 \quad{ }^{2}$ Marine Megafauna Foundation, Truckee, California, USA

5 3Biology Department, Lamar University, Beaumont, TX 77710, USA

6 *Corresponding author: Present address, ${ }^{4}$ Center for Fisheries, Aquaculture and Aquatic

7 Sciences, Southern Illinois University Carbondale, Carbondale IL 62901, USA; Phone:

8 1+618+713+7960; Email; tomkashi@gmail.com 
Introduction

Sharks and rays are increasingly being identified as high-risk species for extinction, prompting urgent assessments of their local or regional populations

(Dulvy et al. 2014a). The Reef Manta Ray Manta alfredi (Krefft 1868) and the Giant Manta Ray M. birostris (Walbaum 1792) are currently listed as Vulnerable by the International Union for the Conservation of Nature (IUCN) Red List of Threatened Species in 2011 (Marshall et al. 2011a; Marshall et al. 2011b). Both species have been listed on Appendix I \& II of the Convention for Migratory Species (CMS) and both species were recently awarded Appendix II listing on the Conventions on International Trade in Endangered Species of Wild Fauna and Flora (CITES). These key conservation steps represent the first significant movement to address reported global declines in manta rays (Vincent et al. 2014). Manta rays have been described as having extremely conservative life history traits, representing one of the least fecund elasmobranch species and with one of the lowest maximum intrinsic rates of population increase of any studied Chondrichthyan (Couturier et al. 2012; Dulvy et al. 2014b).

A crucial knowledge gap still exists in the empirical understanding of their population dynamics, management (CITES 2013). DNA-based population studies can complement logistically and financially challenging long-term field studies by providing insights into the patterns of population structure, connectivity, and effective population sizes (Dudgeon et al. 2012; Schwartz et al. 2007).

Apart from land-based sampling at fish landing sites, manta ray tissue samples are typically collected underwater while SCUBA or free diving using hand spears with biopsy punch tips (Figure1). As manta rays are a major attraction for tourism (O'Malley et al. 2013), such sampling activity may not be popular or discouraged in some areas where people fear that the technique might harm the rays, change their behaviour or have a negative impact on tourism (Braithwaite 2010; Huntingford et al. 2006; Rose et al. 2014). Availability of alternative and less invasive methods to collect DNA from manta rays would increase sampling opportunities.

Here we test the feasibility of the collection of body surface mucus from wild manta rays and its effectiveness as a DNA source for PCR-based population genetics studies. Epidermal cells in surface mucus have been successfully used in many studies for humans, livestock, and wild animals (Gustavsson et al. 2009; Le Vin et al. 2011; McClure et al. 2009; Prunier et al. 2012; Smith \& Burgoyne 2004), but only a handful of studies exist that have 
examined large marine fish (Hoolihan et al. 2009; Lieber et al. 2013). Lieber et al. (2013), recently reported an $\sim 75 \%$ PCR success rate using mucus from the Basking Shark Cetorhinus maximus (Gunnerus 1765), stored in $99 \%$ ethanol, in amplifying the high copy number mitochondrial DNA (mtDNA) genes cytochrome c oxidase subunit 1 (CO1) and control region (CR) and the nuclear ribosomal internal transcribed spacer 2 (ITS2) region. The feasibility of using mucus from other sharks and rays has been largely unexplored, particularly in regards to underwater collection, amplification of single copy nuclear genes and microsatellites, and dry storage methods that may eliminate the needs for special shipping considerations and freezers (Smith \& Burgoyne 2004; Williams 2007). Here we report preliminary results on the effectiveness of these techniques, limitations, and its applicability to future manta ray research. We also discuss potential areas for improvement and future directions.

Materials and methods

All procedures were conducted in accordance to the University of Queensland Animal Ethics Committee approval number SBMS/206/11/ARC and Ecuadorian Ministry of the Environment research permits: 009RM-DPM-MA.

Mucus from eighteen Manta birostris was collected on SCUBA from Isla de la Plata in Ecuador $\left(1^{\circ} 1529.62 \mathrm{~S}, 81^{\circ} 425.96 \mathrm{~W}\right)$ between 2 September and 20 September 2012. Samples were obtained using a small toothbrush held in the diver's hand (Video 1) or mounted on an extendable pole (Figure 2). For each sample, the dorsal surface of the ray was rubbed back and forth or in a circular motion $\sim 3-5$ times, then the brush was placed into an individual $50 \mathrm{ml}$ plastic tube to prevent cross contamination. On dry land, approximately $120 \mu 1$ mucus was transferred from the brush with a clean sterile cotton bud and then onto FTA ${ }^{\mathrm{TM}}$ Elute Cards and/or Indicating FTA ${ }^{\mathrm{TM}}$ Elute Cards (GE Healthcare) using three side-to-side motions, $90^{\circ}$ each way (Figure 3), spreading mucus and cells evenly to an area of approximately $625 \mathrm{~mm}^{2}$. These cards, which are impregnated with a chemical formula that lyses cells and denatures proteins upon contact, are designed for room temperature storage and shipment of DNA from biological samples for PCR analysis. The applied volume of liquid samples is the recommended amount to avoid overloading the chemicals (GE Healthcare). Cards were then air dried and placed in separate resealable plastic bags. Samples were then transported via land and air as normal domestic and international postage and kept at room temperature with desiccants until further analysis in the lab.

DNA for downstream analyses was prepared using the recommended simple protocol for FTA ${ }^{\mathrm{TM}}$ 
81 Elute Cards that releases single stranded DNA (ssDNA) into water. Three squares $(6 \mathrm{~mm} \times 6 \mathrm{~mm}$ $82 \times 3$ ) were cut out using a clean scalpel, washed by pulse-vortex in $1.5 \mathrm{ml}$ of sterile water for 5 83 seconds, then placed in $300 \mu \mathrm{l}$ of sterile water and heated at $98^{\circ} \mathrm{C}$ for 30 minutes. At the end of 84 the incubation step, tubes went through 60 times pulse-vortex at a rate approximately one $85 \mathrm{pulse} / \mathrm{second}$. The cut-outs were removed from tubes and eluates were stored at $-20{ }^{\circ} \mathrm{C}$ until 86 further analyses.

The quality and quantity of template DNA was assessed with three commonly used methods: Spectrophotometry (NanoDrop ${ }^{\mathrm{TM}} 1000$, Thermo Scientific), fluorometry (Qubit ${ }^{\mathrm{TM}}{ }_{\text {ssDNA Assay }}$ Kit, Invitrogen), and $1 \%$ agrose gel electrophoresis. Spectrophotometry can be used to estimate DNA concentration based on light absorbance measurements at wavelength $260 \mathrm{~nm}$ (A260). As a number of substances also absorb light at $260 \mathrm{~nm}$, the results may be unreliable or inaccurate when samples are not purified DNA. Lower detection limit of the instrument was $2 \mathrm{ng} / \mu \mathrm{l}$. Fluorometry (Qubit ${ }^{\mathrm{TM}}$ ssDNA Assay Kit, Invitrogen) uses fluorescent-based dyes that bind specifically to DNA, thus more reliable for the quantification of the target molecules. Lower detection limit of the assay employed was $0.05 \mathrm{ng} / \mu \mathrm{l}$. Gel electrophoresis can provide information on DNA quantity and quality. High amount and intact genomic DNA should appear as a bright compact, high-molecular weight band whereas low amount and degraded DNA might appear faint and low-molecular-weight smears..

We performed PCR for mtDNA (ND5), nuclear DNA (RAG1) and three microsatellite loci (MA09, MA14 and MA34) using published protocols and 1 4 $\mu$ l of template DNA in $12 \sim 20 \mu \mathrm{l}$ reaction (Kashiwagi et al. 2012a; Kashiwagi et al. 2012b) with positive and negative controls and replicated experiments. PCR products for ND5 and RAG1 genes were sequenced in both forward and reverse directions and compared with known types (Kashiwagi et al. 2012b) with GenBank Accession numbers FJ235624-FJ235631 and KR703213 - KR703233. PCR products for three microsatellites were genotyped and compared with previously reported size range (Kashiwagi et al. 2012a). Robustness of genotyping results were tested with replicated experiments for their consistency.

Results

Time between sampling and lab analyses ranged from 81 to 343 days. DNA concentration estimated by spectrophotometric measurements of the concentration of DNA templates ranged from 12.18 to $29.00 \mathrm{ng} / \mu \mathrm{l}(23.16 \pm 4.05 \mathrm{ng} / \mu \mathrm{l}$, mean \pm s.d., $\mathrm{n}=18)$. Estimate for blank sample (i.e. card only) was $11.7 \mathrm{ng} / \mu \mathrm{l}$. Absorbance spectra lacked the typical peak at wavelength $260 \mathrm{~nm}$ 
117 preceded by a dip at $230 \mathrm{~nm}$, which was observable in DNA templates prepared from tissue 118 samples using a commercial DNA extraction kit (e.g. Qiagen DNeasy Kit) (Figure 4). Instead, 119 spectra showed high absorbance around wavelength 230 - $240 \mathrm{~nm}$ that was also present in blank 120 sample. Fluorometric measurements ranged from 0.0743 to $2.16 \mathrm{ng} / \mu \mathrm{l}(0.589 \pm 0.536 \mathrm{ng} / \mu \mathrm{l}$, 121 mean \pm s.d., $\mathrm{n}=18$ ). Measurement for blank sample (i.e. card only) was lower than the detection limit of $0.05 \mathrm{ng} / \mu \mathrm{l}$. There was no visible band or smear with gel electrophoresis loaded with 10 $\mu l$ of samples. Samples concentrated approximately ten times by both standard ethanol precipitation and vacuum drying also failed to show a band or smear.

PCR was successful for all five markers (ND5, RAG1 and three microsatellite loci) across all 18 samples. Fourteen of 18 samples showed known M. birostris ND5 haplotypes (Table 1). One sample showed haplotype (MA04) previously only known from M. alfredi. Three new haplotypes were detected (MB13, 14 and 15, GenBank Accession number KR703235, KR703236, and KR707237, respectively), that were within 3 bp differences in comparison to common haplotype MB01. Seventeen of 18 samples showed known M. birostris RAG1 sequence types. One sample showed new sequence type, MBRAG05 (GenBanK Accession Number KR73234), that is uniquely heterozygous $\mathrm{R}=\mathrm{A}+\mathrm{G}$ at position \#615 in comparison to all other known types that are homozygous $\mathrm{G}$ at the position. Size range for microsatellite was $378-394$ (locus MA09), 189 - 221 (locus MA14), and 183 - 189 (MA34), that extended previously reported ranges for these loci, 378, $197-221$, and $185-189$, respectively (Kashiwagi et al. 2012a). Genotyping results were consistent among replicated PCR experiments.

\section{Discussion}

Our results demonstrate that DNA from manta ray mucus collected underwater and stored dry on FTA $^{\mathrm{TM}}$ Elute cards can be reliably used in PCR-based population genetic studies. To our knowledge, this study is the first example involving underwater collection of mucus by SCUBA divers. The advantages of the developed method include: (i) a reduction in sampling gear, (ii) a significantly reduced impact on the sampled organism, (iii) an increased acceptance as a sampling protocol in region of vibrant tourism, and (iv) reliable, dry, room temperature storage of DNA without need for liquid reagents, refrigerator/freezer, and special shipping considerations.

Sampling of manta ray mucus can be relatively easily achieved, but should only be attempted by experienced field researchers that understand the behavior of these animals. Minimal to no reaction to sampling was noted in all samples taken from manta rays in Ecuador by experienced 
153 field researchers (See Video 1). Several collection tools were initially tested to trap mucus from 154 the dorsal and ventral surfaces of mantas including scouring pads, cotton buds, cotton wool, and 155 a small comb, but small disposable toothbrushes were found to be most effective. Adequate

156 amount of samples were obtained using the toothbrush in the hand or attached to an extendable pole, however the former technique was more effective in applying forces to the brush. Researchers wanting to sample individual manta rays that cannot be approached closely underwater or that are sampling manta rays at the surface from a boat may benefit from the latter technique. Larger amount of mucus samples were taken with circular brushing motions than back and forth motions and from the dorsal surface rather than the ventral surface. The black pigment on the dorsal surface (Coles 1916) tinting the mucus helps visual confirmation of mucus on the brush during underwater collection and transferring onto the FTA Elute Cards on land.

DNA yields from FTA Elute cards using the simple purification method were low judging from the lack of visible DNA in gel electrophoresis and fluorometric measurements showing that only three out of 18 templates were above $1 \mathrm{ng} / \mu \mathrm{l}$. The estimated DNA concentration by spectrophotometry is likely to be inaccurate judging from the lack of distinct peak at $260 \mathrm{~nm}$ in spectrometry and positive value in blank sample. This is an expected result judging from the manufacturer's product information (GE Healthcare Life Sciences 2012) and empirical findings (de Vargas Wolfgramm et al. 2009), which state that the single stranded DNA eluted from FTA Elute cards using the simple protocol is often below the lower detection limit of the current spectrophotometer. As such, we recommend flurometric quantitation as an important first step in downstream analyses for avoiding genotyping errors by using too little copy number of template DNA (Taberlet et al. 1996; Taberlet et al. 1999). Furthermore, it is safest to assume that the amount of cell materials in a given volume of mucus is low. Therefore, it is important that the sampler spread the mucus evenly and fully onto the card. Indeed, we observed variable PCR success when preparing DNA template from three $3 \mathrm{~mm}$ diameter punches, where the samples were simply tapped onto the card directly from the brush (Maxwell and Christensen, unpublished data). We are uncertain about substances that produced high spectrophotometry reading $\sim 230$ $240 \mathrm{~nm}$ among mucus and blank samples from FTA card. It appears those impurities and low DNA yield did not interfere with downstream analyses in this study.

Sequencing results and genotyping results confirmed that the targeted DNA of the species was amplified. Discovery of new haplotypes, sequence types and extended size range for microsatellite is as expected because samples from Ecuador were not included in previous studies (Kashiwagi et al. 2012a; Kashiwagi et al. 2012b). Discovery of one M. birostris individual with mtDNA haplotype MA04, that is only $1 \mathrm{bp}$ different from common M. birostris 
189 haplotype MB01, but previously known from $M$. alfredi only, was surprising but interpretable. 190 As the speciation event of M. alfredi and M. birostris was recent, lineage sorting of various 191 genes might not be complete and post divergence hybridization might have occured occasionally 192 (Kashiwagi et al. 2012b). Manta alfredi do not occur in East Pacific Ocean (Kashiwagi et al. 193 2011; Marshall et al. 2011b) and the inspection of the photograph of the individual clearly keys out as Manta birostris (Marshall et al. 2009)(Fig ?). Thus, there is no evidence to support the hypothesis that the observed results are due to hybridization in current generations. Our interpretation is that the results indicate that the current mtDNA marker is yet not informationrich enough to distinguish the two species world-wide.

We successfully sequenced M. alfredi using this method as well (Maxwell and Christensen, unpublished data). We recommend that the potential utilization of mucus samples beyond the basic PCR based assay be explored further because high quality and quantity of DNA will likely become increasingly important for population genomic analyses with emerging technological advancement in high throughput sequencing (Allendorf et al. 2010; Hohenlohe et al. 2012; Narum et al. 2013). Higher yields and purer recovery may be possible by the use of special recovery kit for FTA card (Mas et al. 2007; McClure et al. 2009; Stangegaard et al. 2011) or use of alternative storage media (Allen-Hall \& McNevin 2013; Ivanova \& Kuzmina 2013; Lee et al. 2012). Whole genome amplification may be useful for generating suitable quantities of DNA from minute amounts (Pinard et al. 2006). At the same time, presence of foreign DNA in the mucus and its effect in downstream analyses should be investigated in the near future.

In conclusion, we demonstrated that mucus samples collected underwater can be effectively used for PCR based population genetic studies in manta rays. This newly described method may create new opportunities to study sensitive or threatened species in regions where tissue sampling had been discouraged or prevented previously.

However, tissue sampling remains as the most preferred option for DNA sampling until more conclusive testing on yields and presence of foreign DNA are completed and for additional reasons that tissues are also useful for research applications such as fatty acid and stable isotope analyses (Couturier et al. 2013a; Couturier et al. 2013b).

Acknowledgements

Authors would like to thank Proytecto Mantas Ecuador staff and volunteers for their assistance with collecting mucus samples in Ecuador. We would also like to thank Drs. Stephen Doblin, Kevin Smith and Kevin Dodson for their support of EAM. We thank Jenny Ovenden, Myrna Constantin, James Hereward and Ed Heist for the arrangement of equipment access. 


\section{References}

Allen-Hall A, and McNevin D. 2013. Non-cryogenic forensic tissue preservation in the field: a review. Australian Journal of Forensic Sciences 45:450-460.

Allendorf FW, Hohenlohe PA, and Luikart G. 2010. Genomics and the future of conservation genetics. Nat Rev Genet 11:697-709.

Braithwaite V. 2010. Do fish feel pain? New York, NY: Oxford University Press.

CITES. 2013. Summary record of the eleventh session of Committee I, Sixteenth meeting of the Conference of the Parties Bangkok (Thailand), 3-14 March 2013.

Couturier LIE, Marshall AD, Jaine FRA, Kashiwagi T, Pierce SJ, Townsend KA, Weeks SJ, Bennett MB, and Richardson AJ. 2012. Biology, ecology and conservation of the Mobulidae. Journal of Fish Biology 80:1075-1119.

Couturier LIE, Rohner CA, Richardson AJ, Marshall AD, Jaine FRA, Bennett MB, Townsend KA, Weeks SJ, and Nichols PD. 2013a. Stable isotope and signature fatty acid analyses suggest reef manta rays feed on demersal zooplankton. PLoS ONE 8:e77152.

Couturier LIE, Rohner CA, Richardson AJ, Pierce SJ, Marshall AD, Jaine FRA, Townsend KA, Bennett MB, Weeks SJ, and Nichols PD. 2013b. Unusually high levels of n-6 polyunsaturated fatty acids in whale sharks and reef manta rays. Lipids 48:1029-1034.

de Vargas Wolfgramm E, de Carvalho FM, da Costa Aguiar VR, De Nadai Sartori MP, Hirschfeld-Campolongo GCR, Tsutsumida WM, and Louro ID. 2009. Simplified buccal DNA extraction with FTA® Elute Cards. Forensic Science International: Genetics 3:125-127.

Dudgeon CL, Blower DC, Broderick D, Giles JL, Holmes BJ, Kashiwagi T, Krück NC, Morgan JAT, Tillett BJ, and Ovenden JR. 2012. A review of the application of molecular genetics for fisheries management and conservation of sharks and rays. Journal of Fish Biology 80:1789-1843.

Dulvy NK, Fowler SL, Musick JA, Cavanagh RD, Kyne PM, Harrison LR, Carlson JK, Davidson LN, Fordham SV, Francis MP, Pollock CM, Simpfendorfer CA, Burgess GH, Carpenter KE, Compagno LJ, Ebert DA, Gibson C, Heupel MR, Livingstone SR, Sanciangco JC, Stevens JD, Valenti S, White WT, and Baldwin IT. 2014a. Extinction risk and conservation of the world's sharks and rays. eLife 3.

Dulvy NK, Pardo SA, Simpfendorfer CA, and Carlson JK. 2014b. Diagnosing the dangerous demography of manta rays using life history theory. PeerJ 2:e400.

GE Healthcare Life Sciences. 2012. Nucleic acid sample preparation for down stream analyses, principles and methods. Buckinghamshire, UK: GE Healthcare Life Sciences.

Gustavsson I, Lindell M, Wilander E, Strand A, and Gyllensten U. 2009. Use of FTA card for dry collection, transportation and storage of cervical cell specimen to detect high-risk HPV. J Clin Virol 46:112-116.

Hohenlohe PA, Catchen J, and Cresko WA. 2012. Population genomic analysis of model and nonmodel organisms 
using sequenced RAD tags. Methods Mol Biol 888:235-260.

Hoolihan JP, Perez NF, Horn RL, Fauge RM, Snodgrass D, Bernard AM, and Schultz DR. 2009. Surface mucous as a source of genomic DNA from Atlantic billfishes (Istiophoridae). Fisheries Bulletin 107:339-342.

Huntingford FA, Adams C, Braithwaite VA, Kadri S, Pottinger TG, Sandøe P, and Turnbull JF. 2006. Current issues in fish welfare. Journal of Fish Biology 68:332-372.

Ivanova NV, and Kuzmina ML. 2013. Protocols for dry DNA storage and shipment at room temperature. Molecular Ecology Resources 13:890-898.

Kashiwagi T, Broderick D, Lance S, Bennett M, and Ovenden J. 2012a. Development and characterization of ten microsatellite loci for the reef manta ray Manta alfredi. Conservation Genetics Resources 4:1055-1058.

Kashiwagi T, Marshall AD, Bennett MB, and Ovenden JR. 2011. Habitat segregation and mosaic sympatry of the two species of manta ray in the Indian and Pacific Oceans: Manta alfredi and M. birostris. Marine Biodiversity Records 4:e53.

Kashiwagi T, Marshall AD, Bennett MB, and Ovenden JR. 2012b. The genetic signature of recent speciation in manta rays (Manta alfredi and M. birostris). Mol Phylogenet Evol 64:212-218.

Le Vin AL, Adam A, Tedder A, Arnold KE, and Mable BK. 2011. Validation of swabs as a non-destructive and relatively non-invasive DNA sampling method in fish. Molecular Ecology Resources 11:107-109.

Lee SB, Clabaugh KC, Silva B, Odigie KO, Coble MD, Loreille O, Scheible M, Fourney RM, Stevens J, Carmody GR, Parsons TJ, Pozder A, Eisenberg AJ, Budowle B, Ahmad T, Miller RW, and Crouse CA. 2012. Assessing a novel room temperature DNA storage medium for forensic biological samples. Forensic Science International: Genetics 6:31-40.

Lieber L, Berrow S, Johnston E, Hall G, Hall J, Gubili C, Sims DW, Jones CS, and Noble LR. 2013. Mucus: aiding elasmobranch conservation through non-invasive genetic sampling. Endangered Species Research 21:215222.

Marshall AD, Bennett MB, Kodja G, Hinojosa-Alvarez S, Galván-Magaña F, Harding M, Stevens G, and Kashiwagi T. 2011a. Manta birostris. Available at http://www.iucnredlist.org (accessed 12 December 2014).

Marshall AD, Compagno LJV, and Bennett MB. 2009. Redescription of genus Manta with resurrection of Manta alfredi (Krefft, 1868) (Chondrichthyes; Myliobatoidei; Mobulidae). Zootaxa 2301:1-28

Marshall AD, Kashiwagi T, Bennett MB, Deakos M, Stevens G, McGregor F, Clark T, Ishihara H, and Sato K. 2011b. Manta alfredi. Available at http://www.iucnredlist.org (accessed 12 December 2014).

Mas S, Crescenti A, Gassó P, Vidal-Taboada JM, and Lafuente A. 2007. DNA cards: determinants of DNA yield and quality in collecting genetic samples for pharmacogenetic studies. Basic \& Clinical Pharmacology \& Toxicology 101:132-137.

McClure MC, McKay SD, Schnabel RD, and Taylor JF. 2009. Assessment of DNA extracted from FTA cards for use on the Illumina iSelect BeadChip. BMC Res Notes 2:107.

Narum SR, Buerkle CA, Davey JW, Miller MR, and Hohenlohe PA. 2013. Genotyping-by-sequencing in ecological and conservation genomics. Molecular Ecology 22:2841-2847. 
O'Malley MP, Lee-Brooks K, and Medd HB. 2013. The global economic impact of manta ray watching tourism. PLoS ONE 8:e65051.

Pinard R, de Winter A, Sarkis G, Gerstein M, Tartaro K, Plant R, Egholm M, Rothberg J, and Leamon J. 2006. Assessment of whole genome amplification-induced bias through high-throughput, massively parallel whole genome sequencing. BMC Genomics 7:216.

Prunier J, Kaufmann B, Grolet O, Picard D, Pompanon F, and Joly P. 2012. Skin swabbing as a new efficient DNA sampling technique in amphibians, and 14 new microsatellite markers in the alpine newt (Ichthyosaura alpestris). Molecular Ecology Resources 12:524-531.

Rose JD, Arlinghaus R, Cooke SJ, Diggles BK, Sawynok W, Stevens ED, and Wynne CDL. 2014. Can fish really feel pain? Fish and Fisheries 15:97-133.

Schwartz MK, Luikart G, and Waples RS. 2007. Genetic monitoring as a promising tool for conservation and management. Trends in Ecology \& Evolution 22:25-33.

Smith L, and Burgoyne L. 2004. Collecting, archiving and processing DNA from wildlife samples using FTA(R) databasing paper. BMC Ecology 4:4.

Stangegaard M, Ferrero-Miliani L, Børsting C, Frank-Hansen R, Hansen AJ, and Morling N. 2011. Repeated extraction of DNA from FTA cards. Forensic Science International: Genetics Supplement Series 3:e345e346.

Taberlet P, Griffin S, Goossens B, Questiau S, Manceau V, Escaravage N, Waits LP, and Bouvet J. 1996. Reliable Genotyping of Samples with Very Low DNA Quantities Using PCR. Nucleic Acids Research 24:31893194.

Taberlet P, Waits LP, and Luikart G. 1999. Noninvasive genetic sampling: look before you leap. Trends in Ecology \& Evolution 14:323-327.

Vincent ACJ, Sadovy de Mitcheson YJ, Fowler SL, and Lieberman S. 2014. The role of CITES in the conservation of marine fishes subject to international trade. Fish and Fisheries 15:563-592.

Williams ST. 2007. Safe and legal shipment of tissue samples: does it affect DNA quality? J Mollus Stud 73:416418. 
Figure 1 (on next page)

Tissue sampling with a biopsy tip and a hand spear 


\section{PeerJ Reviewing Manuscript}

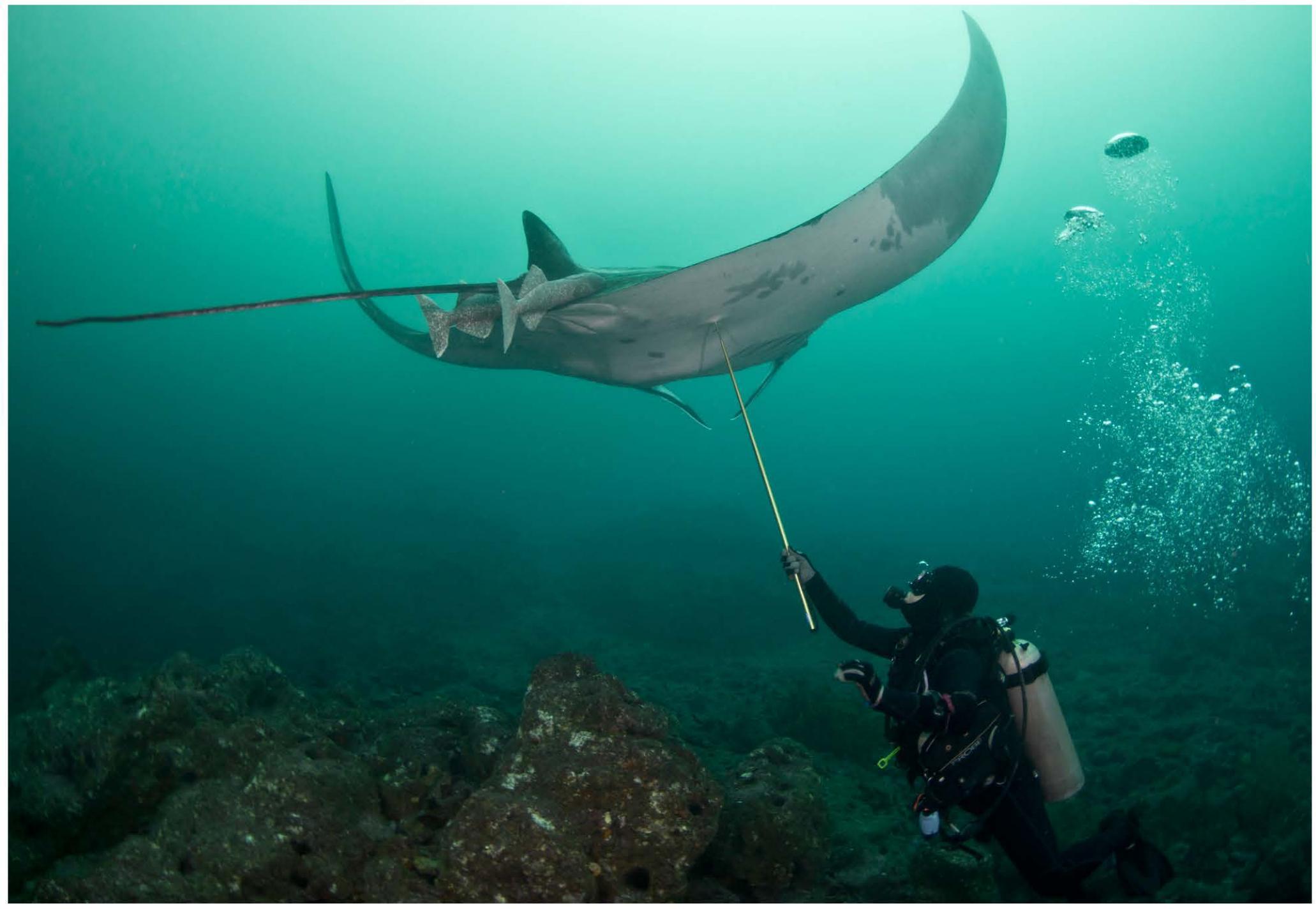


Figure 2 (on next page)

Mucus sampling with a toothbrush mounted on an extendable pole 


\section{PeerJ Reviewing Manuscript}

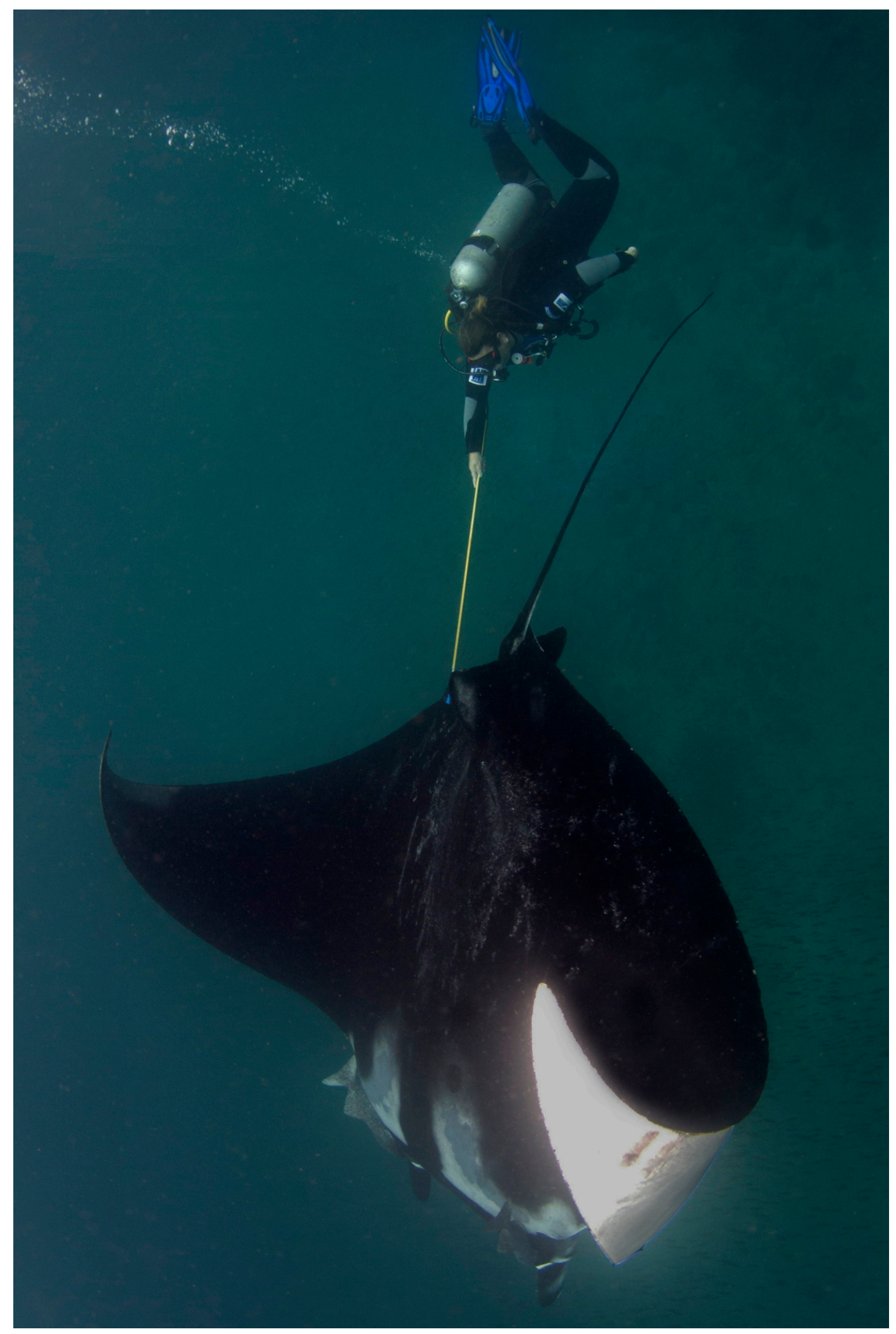


Figure 3 (on next page)

Application of mucus to FTA card.

(a) Black mucus collected on toothbrush, (b) Cotton bud with 120 $\mu$ l of mucus, (c) Transferring mucus onto FTA card using three side-to-side motions, $90^{\circ}$ each way, (d) FTA card with mucus sample. 

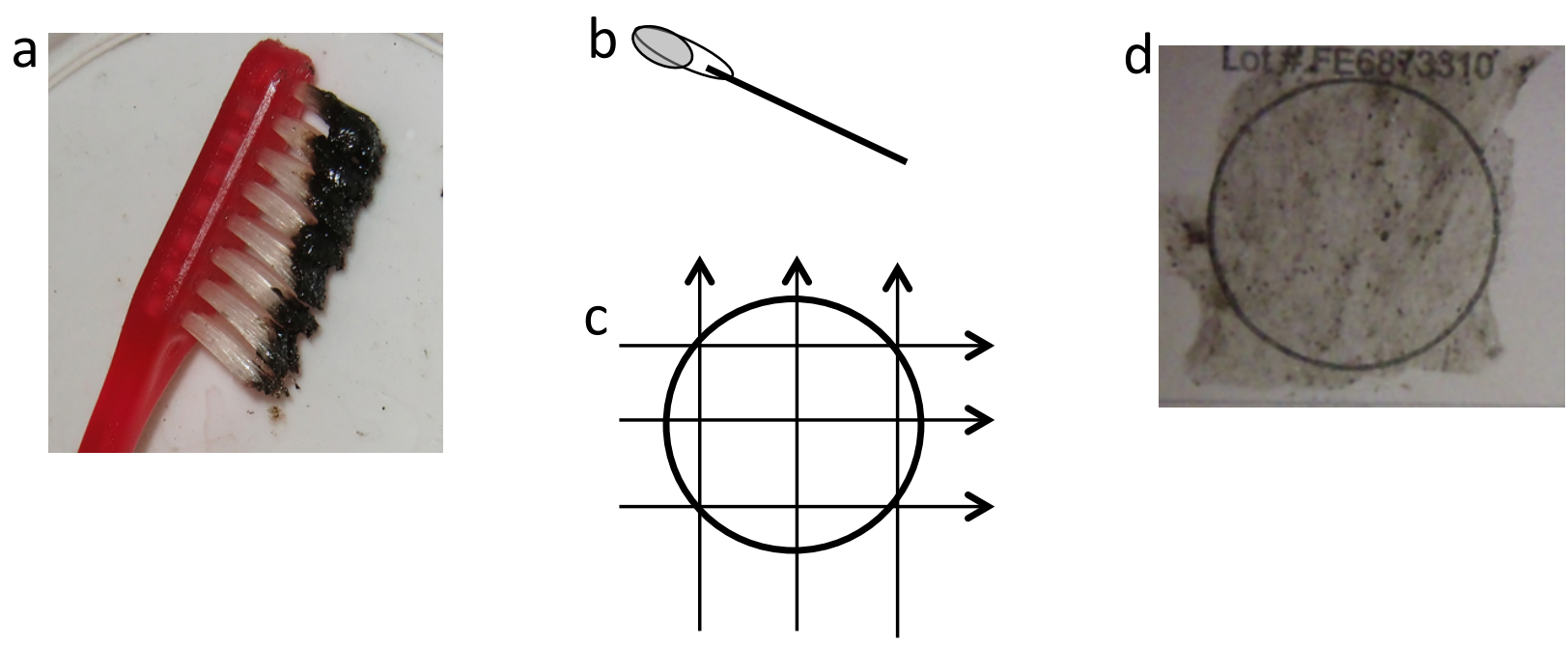
Figure 4(on next page)

Absorbance spectrum of DNA prepared from mucus samples (grey lines), blank (i.e. card only, black dotted) and a tissue sample with DNA extraction kit (black solid) measured by Nanodrop ${ }^{\mathrm{TM}}$. 


\section{Table 1 (on next page)}

Sequencing and genotyping results. 
1 Table 1. Sequencing and genotyping results.

\begin{tabular}{|l|l|l|c|c|c|c|c|c|}
\hline Sample Name & RAG1 & ND5 & \multicolumn{7}{|c|}{ Microsatellite loci } \\
\hline & & & MA09 & MA09 & MA14 & MA14 & MA34 & MA34 \\
\hline EC01 & MBRAG01 & MB06 & 378 & 378 & 201 & 209 & 187 & 187 \\
\hline EC02 & MBRAG01 & MB05 & 378 & 378 & 197 & 201 & 189 & 189 \\
\hline EC03 & MBRAG01 & MB06 & 378 & 378 & 201 & 209 & 187 & 187 \\
\hline EC04 & MBRAG05* & MB06 & 378 & 378 & 197 & 201 & 189 & 189 \\
\hline EC05 & MBRAG01 & MB01 & 378 & 390 & 201 & 217 & 189 & 189 \\
\hline EC06 & MBRAG01 & MB01 & 378 & 386 & 209 & 221 & 185 & 187 \\
\hline EC07 & MBRAG02 & MA04 & 378 & 378 & 197 & 201 & 185 & 187 \\
\hline EC08 & MBRAG01 & MB01 & 378 & 386 & 209 & 221 & 185 & 187 \\
\hline EC09 & MBRAG01 & MB13* & 378 & 390 & 197 & 209 & 187 & 191 \\
\hline EC10 & MBRAG01 & MB01 & 378 & 394 & 193 & 221 & 187 & 187 \\
\hline EC11 & MBRAG01 & MB01 & 378 & 390 & 189 & 201 & 187 & 187 \\
\hline EC12 & MBRAG01 & MB01 & 386 & 390 & 201 & 201 & 187 & 187 \\
\hline EC13 & MBRAG01 & MB01 & 378 & 390 & 197 & 201 & 187 & 189 \\
\hline EC14 & MBRAG02 & MB01 & 378 & 378 & 197 & 201 & 187 & 187 \\
\hline EC15 & MBRAG01 & MB14* & 378 & 390 & 189 & 201 & 187 & 187 \\
\hline EC16 & MBRAG02 & MB15* & 378 & 378 & 201 & 221 & 187 & 187 \\
\hline EC17 & MBRAG02 & MB01 & 378 & 378 & 197 & 201 & 183 & 187 \\
\hline EC18 & MBRAG02 & MB05 & 378 & 378 & 189 & 201 & 183 & 187 \\
\hline
\end{tabular}

2 *Newly detected sequence types in this study (GenBank: KR73234-KR73237). Sequence types without superscript are as Kashiwagi

3 et al (2012b) (GenBank: FJ235624 - FJ235631 and KR703213 - KR703233). 